\title{
PROGRAM OF THE CONFERENCE
}

\section{"ECONOMIC GROWTH AND SOCIAL EQUITY CONFERENCE ON NICHOLAS KALDOR'S LEGACY IN THE $21^{\text {ST }}$ CENTURY"}

September 30, 2016-Corvinus University of Budapest, Hungary

\subsection{0 - 12.30 Introduction and keynote speeches}

Welcome by András Lánczi (Rector of the Corvinus University of Budapest)

Introduction by Mihály Simai (Corvinus University of Budapest) and László Andor (Corvinus University of Budapest)

Anthony Thirlwall (University of Kent): Nicholas Kaldor's Insights into the Applied Economics of Growth and Development (or Why I Became a Kaldorian)

Robert Skidelsky (University of Warwick): Stylized Facts

Frances Stewart (University of Oxford): Sustainability and Inequality - is there a Conflict between the Two?

Mary Kaldor (London School of Economics): The Contemporary Relevance of the US Strategic Bombing Survey

Michael Landesmann (The Vienna Institute for International Economic Studies and Johannes Kepler University, Linz): Nicholas Kaldor and European Integration

Gábor Oblath (Institute of Economics, Centre for Economic and Regional Studies, Hungarian Academy of Sciences and Corvinus University of Budapest): The 'Kaldor-Paradox' - A Reappraisal (Real Exchange Rate Changes, Export Performance, Currency Misalignments and Economic Growth in the Member States of the European Union)

Questions and answers

\subsection{0 - 15.30 Parallel workshops}

Workshop 1 - Kaldor's legacy and economic policy

Chair: Sebastian Dullien (University of Applied Sciences, Berlin)

Aladár Madarász (Institute of Economics, Centre for Economic and Regional Studies, Hungarian Academy of Sciences and Corvinus University of Budapest): International Monetary Policy and the Price Level - Káldor's Hungarian Article on the Macmillan Report in 1931 
Péter Mihályi (Corvinus University of Budapest): Kaldor and Kornai on "Economics without Equilibrium" - Two Life Courses

André Mommen (University of Amsterdam): Káldor's versus Varga's Three-Year Economic Reconstruction Plan (1947)

Matteo Laruffa (LUISS Guido Carli University, Rome): The Unresolved Problems of the European Fiscal Rules and Their Political, Social and Economic Impact

Andrew Watt (Macroeconomic Policy Institute, Berlin): Current Accounts, Wages, Demand - Achieving Balanced Growth and Convergence in the Euro Area

Workshop 2 - Productivity and growth

Chair: Grzegorz W. Kolodko (Kozminski University, Warsaw)

Alberto Bagnai (University of Chieti - Pescara): The Pre-Great Recession Productivity Slowdown - Neoclassical vs. Post-Keynesian Explanations

Leon Podkaminer (The Vienna Institute for International Economic Studies): The Slowdown in Labor Productivity Growth is an Effect of Economic Stagnation Rather than its Cause

Zoltán Pogátsa (University of West Hungary): Growth and Productivity in Káldor's Works

Krisztina Söreg (National University of Public Service, Budapest): Persistent Growth Slowdowns in Fast-Growing Middle-Income Economies

\section{Workshop 3 - Incomes and distribution}

Chair: Kitty Stewart (London School of Economics)

Per F. Andersson (Lund University): Institutions and Left-Wing Tax Strategy Britain and Sweden Compared

Anita Pelle (University of Szeged): The Intra-EU Migration Challenge from a Socio-Economic Perspective

Andrew Ryder (Corvinus University of Budapest): Roma and a Social Europe The Role of Redistribution, Emancipatory Politics and Intervention

\subsection{0 - 17.30 Round table: The economics of the European Union}

Chair: Paul Adamson (Forum Europe, Brussels)

Júlia Király (International Business School and Corvinus University of Budapest)

Michael Landesmann (The Vienna Institute for International Economic Studies and Johannes Kepler University, Linz)

George Pagoulatos (Athens University of Economics and Business) 


\section{INSTRUCTIONS FOR AUTHORS}

Acta Oeconomica publishes original research papers, review articles, book reviews and announcements in the field of economics. Papers are accepted on the understanding that they have not been published or submitted for publication elsewhere in English language and that they are subject to peer review. Papers accepted for publication by the editorial board are subject to editorial revision.

\section{Submission of manuscripts}

Acta Oeconomica insists on electronic submission of manuscripts. Manuscripts should be sent as attachment by e-mail in MS Word (.doc or .docx) file to judit.vanyai@krtk.mta.hu with operating system MS Windows $95 / 98$ or later versions.

\section{Presentation of manuscripts}

Manuscripts should be written in clear, concise, and grammatically correct English. The order should be as follows: title page, abstract, keywords, Journal of Economic Literature classification numbers, text, references, tables, figure captions, appendix.

Title page. The title should be concise and informative. A short running title of no more than 40 characters should also be supplied. This is followed by the first name(s) and surname of the author(s), and the name of the institution the author works at. The mailing address and e-mail address of the corresponding author must also be given in a footnote.

Abstract should not exceed 200 words.

Keywords and literature classification index should not exceed 10 items.

Acknowledgements should be placed on the first page.

References in the text should follow the author-date format without comma. Where there are more than two authors, the name of the first author should be used, followed by et al. Publications by the same author(s) in the same year should be listed as e.g. (1999a), (1999b). List the references in chronological order in the text and in alphabetical order at the end of the paper. The style and punctuation of references should conform to that used in the journal. See the following examples:

- Hámori, J. R. - Kovács, B. J. - Szabó, G. (1998): Felzárkózás és előretörés (Catching up and Go ahead). Közgazdasági Szemle, 13(10): 45-53.

- Smith, B. G. (1998): Financial Problems and their Solutions in the Transition Countries. In: Gordon, M. - Ratherford, R. K. (eds): Approaching to the EU. London: Macmillan, pp. 234-245.

- Zacher, M. (1996): Evolution and Revolution in Industrial Economics.2 $2^{\text {nd }}$ ed., Budapest: Közgazdasági Könyvkiadó.

Tables. Each, bearing a title, should be self-explanatory. They should be mentioned in the text, numbered consecutively with Arabic numerals and placed on separate sheets at the end of the manuscript, following the References. Their approximate position should be indicated in the manuscript. Figures should be submitted electronically in TIFF or JPG file format (min. 300 dpi). Excel files with edited diagrams and charts are also accepted. Please apply only black and white colours. In the legend use different signs, not colours. All figures should be numbered consecutively with Arabic numerals and the approximate position should be indicated in the text.

Permissions. It is the responsibility of the author to obtain written permission for quotations, and for the reprinting of illustrations or tables. 
CVs of the authors should not exceed 200 words. The style should conform to that used in the journal.

Advertisements may be inserted by the Publisher.

Proofs and reprints. Proofs will be sent to the corresponding author electronically in pdf format, who is requested to return it to the Editor within 5 days of receipt. Ten reprints of each paper are supplied free of charge to the corresponding author. Additional reprints can be ordered on a Reprint Order.

A copy of the Copyright Transfer Statement will be sent to the authors of the papers accepted for publication. Manuscripts will be processed only after receiving the signed copy of the statement.

Open Access. Authors can use the Optional Open Access publication model for a specific publishing fee. It is an option for the author to pay the Article Processing Charge (APC) and have the final full text version of his/her article published as an Open Access one. The full text of an Open Access paper is freely accessible through the official website of the journal. The peer review process and the quality requirements, as well as the publishing process are the same in case of both traditional and Open Access manuscripts. Both accepted new manuscripts and papers published earlier can be Open Access. The APC of an Open Access article is 590 EUR (770 USD) + VAT, where applicable, but it can be even less. Akadémiai Kiadó offers discounts for Hungarian authors, institutions of low-and middle-income countries and Editorial Board members. Discounts may not be combined. The above fee does not include any normal (excess) page fees and colour charges. By signing the Open Access License Agreement and paying the APC, the Author retains the ownership and further rights related to the Article while ensuring the wide accessibility of the Article in the written and electronic media controlled by Akadémiai Kiadó. See www.oopenart.com for details. Should you have any questions, please contact the editors of the journal. 


\section{REFEREEING PROCEDURE}

The complete refereeing process for the journal is double-blind. The author(s) and the referees then cannot have any knowledge of each other at any time.

Each paper is refereed by (at least) two referees.

The assignment of three (two active and one on reserve) referees is made by the Editorial Board. To be able to do so each member of the Board receives an anonymous, maximum one page long abstract of the paper(s).

The decision after the first round of refereeing can be:

1. accept the paper without further corrections,

2. accept the paper with corrections and changes suggested by the referees and the editor(s),

3. request major changes and the paper is returned to the referees for a second round of refereeing,

4. the paper should be completely re-written along some well-specified guidelines and the journal would then accept a re-submission (the paper would be considered a new submission) and

5. outright rejection.

In order to increase the effectiveness of the review process, authors are kindly asked to respond to the comments and suggestions of the referees.

The Editorial Board based on the referee's report makes the final acceptance or rejection decision. The Editor-in-Chief ensures the absolute confidentiality of the whole process. 